\title{
VPLYV MIESTNYCH AKČNÝCH SKUPÍN NA PODPORU ROZVOJA CESTOVNÉHO RUCHU, NA PRÍKLADE MIESTNEJ AKČNEJ SKUPINY (MAS) MAGURA-STRÁŽOV
}

\author{
Tomáš Kováč, Ivan Laco, Michaela Kalivodová, Martin Boltižiar
}

\begin{abstract}
Local action groups came into existence based on LEADER, the programm of European Union, which enable financing from European Union. These compositions of public and private sectors has a role to support and development of rural regions with a regard to preserving sustainable development. Even though there are researh papers discussing different topics related to LAGs, research aimed to influence of LAGs to turism are not numerous. The local action group (LAG) Magura-Strážov was chosen as a study case behalf of nature and historical potencial of the region for development of turism and consecutive economic benefits for the local population. The research paper analyzes priority strategies of CLLD, potential for turism, includes SWOT analysis of MAS Magura-Strážov functioning, summarizes realized projects and proposes specific actions that support turism developlment.
\end{abstract}

Keywords: LAG, Magura-Strážov, development of tourism, LEADER

\section{Úvod}

Pod pojmom miestna akčná skupina (MAS) rozumieme spojenie členov zo súkromného, občianskeho a verejného sektora, pričom spoločným faktorom je celistvé územie (NSRV, 2015b). Fungujú na základe prístupu LEADER („Spájanie aktivít, ktoré podporujú hospodársky rozvoj vidieka"), ktorý vznikol na podnet Európskej komisie. Jeho úlohou je, prostredníctvom stratégií miestneho rozvoja vedeného komunitou (CLLD), rozvoj vidieka a využitie jeho potenciálu. Viac ako polovica obyvatel'ov Európskej únie (EÚ) žije na vidieku, ktorý pokrýva $90 \%$ územia EÚ z čoho vyplýva, že je vel'mi dôležité podporovat' rozvoj práve týchto území. Hlavnou ideou je efektívne zapájanie miestnych obyvatel'ov z rôznych sektorov a teda uplatňovanie princípu ,zdola nahor“, a sú to práve oni, ktorí toto územie dôverne poznajú. Územie MAS Magura-Strážov sme vybrali ako príklad územia charakteristické svojím vel'kým, avšak nedostatočne využitým, prírodným a kultúrnym potenciálom pre rozvoj cestovného ruchu a v tomto kontexte taktiež poskytuje priestor pre iniciatívu a realizáciu projektov MAS Magura-Strážov. 


\section{Teoreticko-metodické východiská}

Prvé zmienky o výskumoch týkajúcich sa MAS a prístupu LEADER sa začali objavovat' v roku 2000 (Thuesen, 2010). Tejto téme ako aj rozvoju vidieka sa venuje taktiež niekol'ko monografí́, ako príklad uvádzame prácu Social capital and local development od Pisani et al. (2015). Publikácie sa sústred’ujú najmä na územie Dánska (Thuesen, 2010), Pol'ska (Furmankiewicz, 2012, 2013), Rumunska (Paul, 2015), Slovinska (Volk, Bojnec, 2014), Španielska (Navarro et al., 2018) či Talianska (Navarro et al., 2018). Najčastejšie sa venujú všeobecnému fungovaniu MAS (Furmankiewicz, 2013), problémom, ktoré sa pri fungovaní vyskytujú (Furmankiewicz, 2012, Navarro et al., 2016) ako aj financovaniu (Volk - Bojnec, 2014). Prínosnú publikáciu napísali Lopolito et al. (2011), ktorí zostavili vzorec na ohodnotenie efektívnosti MAS. Napriek pomerne vel'kému počtu publikácií tykajúcich sa MAS zaznamenávame menej prác, ktoré sa venujú rozvoju vidieka prostredníctvom cestovného ruchu (Petrovič, Muchová, 2013, Boltižiar, 2001).

\section{Fungovanie a možnosti získavania finančných prostriedkov MAS Magura- Strážov}

Európska komisia v programovom období 2014-2020 zaviedla možnost' využívania finančných prostriedkov z rôznych zdrojov ako napr. integrovaného rozvoja vidieka a d'alších fondov EÚ. Ide o tzv. multifinancovanie prostredníctvom miestneho rozvoja, ktorý je riadený komunitou CLLD (Kováč, 2017, Wisterová, 2016).

CLLD z anglického výrazu (Community Led Local Development) je nástroj na zapájanie miestnych aktérov do rozhodovania o sociálnom, environmentálnom a ekonomickom rozvoji svojho územia. Ciele stratégie CLLD nadväzujú nielen na potreby regiónu, ale odrážajú v sebe aj ciele koncepčných dokumentov, ku ktorých napíňaniu sa zaviazala SR. Ide predovšetkým o stratégiu 2020 (Európska Komisia, 2010), Programu rozvoja vidieka 2014 - 2020 (PRV) a Integrovaný regionálny operačný program 2014-2020 (IROP, 2014). V súlade s Partnerskou dohodou SR na roky 2014-2020 sa na podporu nástroja CLLD využívajú dva EÚ fondy. Využíva sa Európsky pol’nohospodársky fond pre rozvoj vidieka (EPFRV) prostredníctvom PRV 2014-2020 a Európsky fond regionálneho rozvoja (EFRR) prostredníctvom IROP 2014-2020. Obsahovým základom pre stratégie CLLD sú PRV a IROP (NSRV, 2015a).

Pre fungovanie programu LEADER je dôležitých 7 hlavných princípov, (zdola nahor, územno-miestny princíp, lokálne partnerstvo, integrovaný prístup, siet’ovanie, inovácia a národná a medzinárodná spolupráca), ktoré sa navzájom ovplyvňujú, dopín̆ajú a sú medzinárodne uznávanými v EÚ (Leader SVK, 2010).

MAS je zoskupenie predstavitel'ov, v ktorých na úrovni rozhodovania nemá žiadna záujmová skupina viac ako 49 \% hlasovacích práv. Každá MAS musí 
spĺn̆at' základné podmienky týkajúce sa partnerstva, územia pôsobnosti a stratégie rozvoja. Počet obyvatel'ov, ktorí žijú v území MAS, je presne ohraničený. Pohybuje sa od 10000 obyvatel'ov do 150000 obyvatel'ov. Hustota obyvatel'stva MAS nesmie byt' vyššia ako 150 obyvatel'ov $/ \mathrm{km}^{2}$. Zastúpená je občianskym združením v zmysle zákona č. 83/1990 Zb. o združovaní občanov a má právnu subjektivitu, taktiež má vytvorenú štruktúru orgánov, ktoré sú schopné spravovat' verejné prostriedky a manažovat' činnost' MAS. Zároveň musí mat' najmenej 7 obcí a členovia MAS musia mat' na území MAS trvalý alebo prechodný pobyt, sídlo alebo prevádzku. Každá MAS musí mat' vypracovanú stratégiu CLLD s jasne formulovanými ciel'mi a opatreniami, ktoré budú prispievat' $\mathrm{k}$ podpore miestneho rozvoja. Na území SR implementácia prebieha prostredníctvom PRV SR 20142020 pod záštitou Ministerstva pôdohospodárstva a rozvoja vidieka (Leader SVK, 2010, Zákon č. 83/1990, NSRV, 2015b).

\section{Administratívny proces schválenia projektu}

Proces získavania finančných zdrojov z fondu EPFRV prebieha nasledovne. Ako prvé MAS vyhlási výzvu na Implementáciu Integrovanej stratégie rozvoja územia pre určité opatrenie. Každá výzva na implementáciu stratégie musí byt' zverejnená minimálne 14 pracovných dní. V tomto období je potrebné podat' na MAS projekt. Konečný prijímatel' podpory musí predložit' projekt manažérovi MAS, ktorý vykoná formálnu kontrolu projektu, prevezme ho a vystaví prijímatel'ovi potvrdenie o prevzatí. Následne MAS zvolá zasadnutie výberovej komisie. Výberová komisia vyhodnotí všetky prijaté projekty v rámci jednej výzvy a vyčlení projekty, ktoré splnili všetky podmienky formálnej a administratívnej kontroly a predloží ich výkonnému orgánu MAS, ktorý potom schval'uje tieto projekty na financovanie z PRV 2014-2020. Schválené projekty MAS posiela na Pôdohospodársku platobnú agentúru (PPA), ktorá do 40 pracovných dní vykoná kontrolu dokumentov a predložených projektov. Zároveň kontroluje aj projekty, ktoré boli na úrovni MAS vylúčené. Po ukončení kontroly vydá PPA konečnému prijímatel'ovi - predkladatel'ovi projektu „Rozhodnutie o schválení žiadosti o nenávratný finančný príspevok z PRV SR 2014-2020" a do 15 dní od vydania tohto rozhodnutia predloží návrh zmluvy medzi PPA a konečným žiadatel’om. EÚ akreditované platobné agentúry sú EFRR a EPFRV. Na Slovensku je to PPA, ktorá patrí pod Ministerstvo pôdohospodárstva a rozvoja vidieka (NARIADENIE EÚ č. 1303/2013).

\section{História MAS Magura-Strážov}

Základy MAS boli položené v roku 2003 vznikom združenia obcí Mikroregión Magura-Strážov, ktoré tvorilo 13 členských obcí: Temeš, Čavoj, Dlžín, Horná Poruba, Kostolná Ves, Košecké Podhradie, Liešt’any, Šútovce, Seč, 
Valaská Belá, Zliechov, Nevidzany a Rudnianska Lehota. Ustanovujúce zasadnutie sa konalo v obci Temeš. V roku 2007 sa k pôvodným 13 (podhorské obce) mikroregiónu pripojilo 6 (prímestských) obcí: Opatovce nad Nitrou, Lazany, Košeca, Nitrianske Rudno, Kocurany, Kanianka a mesto Bojnice, aby vytvorili stabilnejší celok MAS Magura-Strážov. Tento celok funguje v rovnakom zložení aj v súčasnosti. V októbri 2007 bola na Ministerstve vnútra Slovenskej republiky zaregistrovaná MAS Magura-Strážov so sídlom v obci Kanianka. Od roku 2015 sa sídlo MAS presunulo do obce Šútovce. (Stratégia CLLD,2015, Kováč, 2017).

\section{Vymedzenie a stručná charakteristika územia MAS Magura-Strážov}

Územie MAS v rámci Slovenskej republiky patrí do Trenčianskeho samosprávneho kraja (TSK), pričom MAS sa rozprestiera na území dvoch okresov a to Prievidza a Ilava (mapa 1). Celková plocha MAS Magura-Strážov, je 339,36 km² (Stratégia CLLD, 2015, Kováč, 2017, Hrnčiarová, red. 2002).

Podl'a geomorfologického členenia Mazúra a Lukniša (1986) zarad’ujeme územie MAS do celkov Strážovské vrchy a Hornonitrianska kotlina. Najvyšším bodom je vrch Strážov 1212,3 m n. m., ktorý sa nachádza nad obcou Zliechov.

V rámci klimatického členenia Slovenskej republiky sa v danom území nachádzajú všetky klimatické oblasti a to teplá oblast', mierne teplá oblast' a chladná oblast' (Lapin a kol., 2002).

$\mathrm{V}$ rámci širších vzt'ahov patrí územie do umoria Čierneho mora a povodia rieky Nitry, ktorá je zároveň najvýznamnejšou riekou v území.

Mapa 1: Vymedzenie územia MAS Magura-Strážov Map 1: Definition of the LAG territory Magura-Strazov

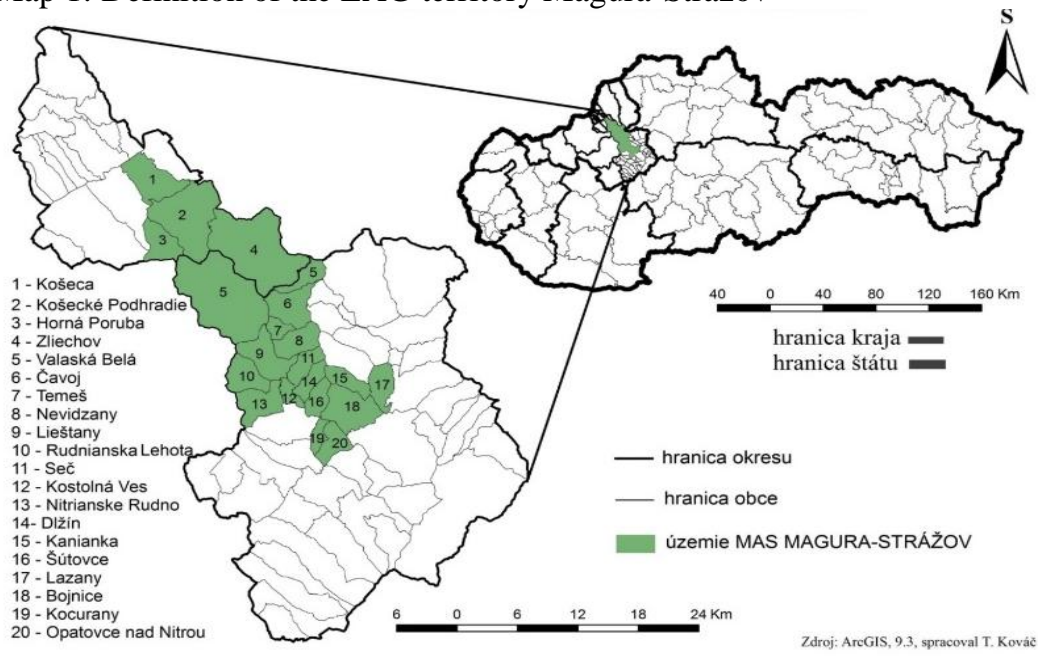


V rámci fytogeografického členenia v súlade s Kolénym a Barkom (2002) zarad'ujeme územie v rámci Európy do oblasti Holarktis, Eurosibírskej podoblasti, stredoeurópskej provincie a do oblasti západokarpatskej flóry (Carpaticum occidentale). Na územie MAS Magura-Strážov zasahuje obvod predkarpatskej flóry (Praecarpaticum) (Brtek a kol., 1979, Kováč, 2017).

Z hl'adiska zoogeografického členenia terestrického biocyklu patrí skúmané územie do Eurosibírskej podoblasti, provincie listnatých lesov, podkarpatský úsek. (Lukniš a kol., 1972, Hensel, Krno, 2002).

Na území MAS Magura-Strážov sa nachádza vel'koplošné chránené územie (CHKO Strážovské vrchy), d’alej sa tu nachádza 9 maloplošných chránených území a 2 európske chránené územia a taktiež tu nájdeme aj chránené stromy (Kováč a kol., 2018).

\section{Potenciál cestovného ruchu v MAS Magura-Strážov}

Územie MAS disponuje mnohými prírodnými, kultúrnymi ale aj inými zaujímavost’ami, ktoré výrazne ovplyvňujú jej potenciál. Za hlavný rekreačný potenciál MAS považujeme výskyt geotermálnych vôd, čím sa stáva územie významnou rekreačnou oblast'ou. V území nachádzame významné kúpele Bojnice (liečba nervových chorôb a chorôb pohybového ústrojenstva. V MAS sa nachádza aj mnoho chránených území, napríklad územie európskeho významu Strážovské vrchy, ktoré disponuje mnohými biotopmi európskeho významu (bukové a jedlové kvetnaté lesy a mnohé iné). Taktiež sa tu nachádza prírodná rezervácia Temešská skala, ktorá je charakteristická kvôli vrcholovej časti, pozostávajúcej zo strmej skalnej steny, ktorá predstavuje výraznú krajinnú dominantu. $Z$ druhov európskeho významu sa tú vyskytujú: črievičník papučkový (Cypripedium calceolus), poniklec prostredný (Pulsatilla subslavica) a iné, ktorých výskyt na Slovensku nie je zriedkavý.

V MAS sa nachádzajú aj dve vodné nádrže: Vodná nádrž Nitrianske Rudno a Vodná nádrž Kanianka, ktoré sú turisticky vel'mi zaujímavé, čím poskytujú vhodné podmienky na rekreáciu a oddych.

Nachádzajú sa tu aj podhorské obce, ktoré svojimi podmienkami ponúkajú ideálne prostredie na rozvoj agroturistiky, ako aj vidieckeho cestovného ruchu. Tieto obce ponúkajú zdanlivo neporušenú prírodu, siet' turistických a cykloturistických chodníkov, a mnoho iných zaujímavosti, čím vytvárajú z týchto oblastí atraktívnu lokalitu pre príjemný relax s poznávaním histórie a budovaním národného povedomia (Stratégia CLLD, 2015, Kováč, 2017).

\section{SWOT analýza aktivít MAS Magura-Strážov na rozvoj daného územia}

Predložená SWOT analýza (tab. 1) poskytuje prehl'adné zobrazenie pozitív a negatív fungovania MAS. Bola vypracovaná na základe rozboru aktuálnej 
situácie v území, prírodných podmienok, potenciálu oblasti a predchádzajúcej konzultácie s predsedom MAS a členov verejného sektora.

\section{Tab. 1: SWOT analýza aktivít MAS Magura-Strážov vplývajúcich na rozvoj daného územia}

Table 1: SWOT analysis of LAG Magura-Strážov activitie infuencing development of the area

\begin{tabular}{|c|c|}
\hline Silné stránky & Slabé stránky \\
\hline $\begin{array}{l}\text { Región má homogénny charakter z socio- } \\
\text { ekonomického hladiska }\end{array}$ & $\begin{array}{l}\text { Nerovnomerne rozvinutý cestovných ruch } \\
\mathrm{v} \text { jednotlivých obciach (napríklad Bojnice - } \\
\text { nižšia nezamestnanost') }\end{array}$ \\
\hline Rozvoj regiónu ako celku & $\begin{array}{l}\text { Nerovnomerné územné rozmiestnenie } \\
\text { realizácie projektov a finančných zdrojov }\end{array}$ \\
\hline $\begin{array}{l}\text { Možnosti čerpania financií z viacerých } \\
\text { zdrojov (IROP, PRV) }\end{array}$ & Zložitý proces získavania finančných zdrojov \\
\hline $\begin{array}{l}\text { Vyvážené zastúpenie sektorov (verejný - } \\
\text { starostovia, súkromný -podnikatel'ské } \\
\text { subjekty, občiansky - neziskové } \\
\text { a mimovládne organizácie, občania) }\end{array}$ & Prekážky pri realizácii projektov \\
\hline $\begin{array}{l}\text { Rovnomerné územné rozmiestnenie členov } \\
\text { partnerstva }\end{array}$ & Miera vplyvu jednotlivých členov \\
\hline Efektívnejšia komunikácia & Nezhody pri rozhodovaní \\
\hline Jednoduchšie zdiel'anie nových poznatkov & $\begin{array}{l}\text { Pri vel'kom počte členov náročnejšia } \\
\text { komunikácia }\end{array}$ \\
\hline $\begin{array}{l}\text { Účast' jednotlivých členov MAS na iných } \\
\text { projektoch a tým podpora rozvoju celého } \\
\text { regiónu }\end{array}$ & $\begin{array}{l}\text { Neúčast' prípadne nedostatočná účast' } \\
\text { niektorých členov MAS }\end{array}$ \\
\hline Organizácia kultúrnych podujatí & Nedostatočná propagácia tradícií \\
\hline Príležitosti & Ohrozenia \\
\hline Ochota spolupracovat' na rozvoji regiónu & Neochota spolupracovat' na rozvoji regiónu \\
\hline $\begin{array}{l}\text { Záujem o d’alšie čerpanie finančných } \\
\text { prostriedkov }\end{array}$ & $\begin{array}{l}\text { Nízka miera získavania finančných } \\
\text { prostriedkov }\end{array}$ \\
\hline $\begin{array}{l}\text { Využitie vol’ných plôch (potenciál) na účely } \\
\text { rozvoja cestovného ruchu (napr. agrofarmy } \\
\text { - ekoturizmus) }\end{array}$ & $\begin{array}{l}\text { - } \quad \text { Nezáujem jednotlivých subjektov } \\
\text { o rozvoj cestovného ruchu } \\
\text { - } \quad \text { Konkurencia atraktívnych lokalít } \\
\text { z hl'adiska cestovného ruchu } \\
\text { - } \quad \begin{array}{l}\text { Potencionálne ohrozenie a znečistenie } \\
\text { životného prostredia }\end{array}\end{array}$ \\
\hline $\begin{array}{l}\text { Získanie nových kontaktov na nadviazanie } \\
\text { spolupráce }\end{array}$ & $\begin{array}{l}\text { Nedostatočná komunikácia } \\
\text { • Nedostatočná komunikácia a nezhody } \\
\text { v zameraní podujatí }\end{array}$ \\
\hline Vytvorenie spoločných podujatí & $\begin{array}{l}\text { - } \quad \text { Výber miesta pre podujatie } \\
\text { Zodpovednost' za organizáciu daného } \\
\text { podujatia }\end{array}$ \\
\hline $\begin{array}{l}\text { Spolupráca s inými MAS a inými } \\
\text { organizáciami }\end{array}$ & $\begin{array}{l}\text { Nedostatočná komunikácia, rozdiely v } \\
\text { názoroch }\end{array}$ \\
\hline $\begin{array}{l}\text { Medzinárodná spolupráca so zahraničnými } \\
\text { organizáciami (Česká republika) }\end{array}$ & Prekážky v legislatíve \\
\hline
\end{tabular}




\section{Výsledky dotazníkového prieskumu v regióne MAS Magura-Strážov}

V roku 2015 sa uskutočnil MAS dotazník s 12 otázkami týkajúcimi sa spokojnosti občanov s kvalitou života v regióne (Jakubcová et al. 2016), sociálnokultúrnym vyžitím. Spolu sa zapojilo do prieskumu 197 občanov (ob.) vo vekových kategóriách 18-24 rokov (27 ob.), 25-34 rokov (39 ob.), 35-49 rokov (55 ob.), 50-60 rokov (53 ob.) a viac ako 60 rokov (23 ob.) (Stratégia CLLD, 2015). Zahrnutí boli študenti (15), osoby na materskej dovolenke (6), zamestnaní (132), nezamestnaní (19) a dôchodcovia (25).

Pri otázke tykajúcej sa územia $\mathrm{z}$ hl'adiska miesta bývania až 157 respondentov označilo možnost', že územie má krásnu prírodu a čisté ovzdušie, to znamená priaznivé prostredie pre rozvoj turizmu. Až 78\% opýtaných tu plánuje zostat' aj v budúcnosti a tí, ktorí tak nezamýšlajú uvádzajú ako dôvod nedostatok pracovných miest, čo by však väčší dôraz na turizmus čiastočne riešil. Takmer polovica zúčastnených obyvatel'ov $(42 \%)$ hodnotí kultúrno-spoločenské podujatia vel'mi pozitívne (oblast' Bojníc a Nitrianskeho Rudna). Vyzdvihnutý bol však nedostatok podujatí pre mladých. Podujatia a prezentácia folklórnych zvykov sú lákadlom nielen pre slovenských návštevníkov ale aj zahraničných cestovatel'ov (Liu, 2014). Najväčší záujem je o športové aktivity a hudobné vystúpenia. Iba 48 \% obyvatel'ov označilo, že sa zaujíma o dianie v mikroregióne, o niečo menej l'udí (42\%) sa zaujíma o dianie najmä v obci, v ktorej žijú. V tab. číslo 1 sú uvedené zdroje, z ktorých informácie o dianí získavajú. Výsledky poukazujú najmä na nedostatočný spôsob zdiel'ania informácií. Tento dotazníkový prieskum dokazuje, že aktivity MAS, ktoré by podporili cestovný ruch, sú v súlade s požiadavkami miestnych obyvatel'ov.

Graf. 1 : Hlavné zdroje informácií pre miestnych obyvatel'ov o dianí na území MAS Magura-Strážov

Graph 1 : Main sources of information about events for the local residents in the area of LAG

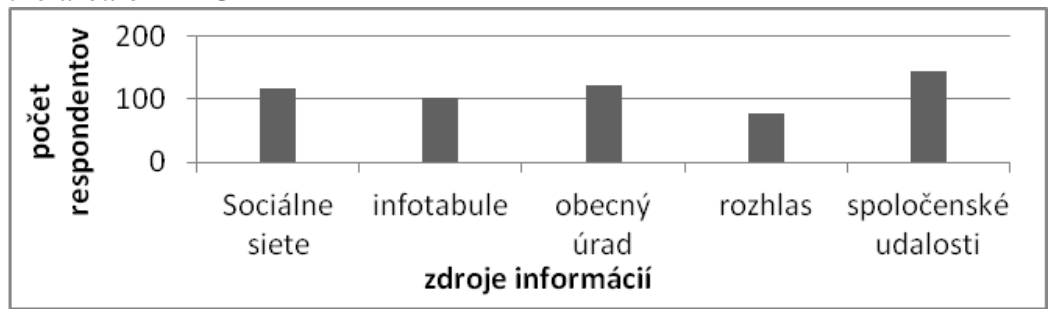

Jedna $\mathrm{z}$ otázok sa týkala aj tradícií, ktoré spájajú opýtaných $\mathrm{s}$ mikroregiónom. Najčastejšie spomínané boli tradičné podujatia ako stavanie mája, hody, Fašiangy a neoddelitel'ná súčast' Slovenského folklóru - l'udové kroje a 
piesne, d’alej výstup na Maguru, festival duchov a strašidiel v Bojniciach a výroba skla vo Valaskej Belej. Všetky aktivity sú pri dostatočnej propagácii nepochybne vel'kým lákadlom pre turistov.

\section{Aktivity MAS Magura-Strážov v území}

Ked’že v programovom období 2007-2013 MAS nezískala štatút MAS, boli počas tohto obdobia na jej území realizované predovšetkým projekty, ktorých predmetom bolo hlavne organizovanie kultúrno-spoločenských aktivít a taktiež aj projekty zamerané na budovanie cyklotrás a turistických trás. Ako príklad uvádzame projekt, ktorý sa uskutočnil $\mathrm{v}$ máji 2008 a to projekt mapovania cyklotrás v spolupráci s MAS Žiar. Ciel'om projektu bolo pripravit' a následne zrealizovat' $\mathrm{v}$ rámci regiónu ucelenú siet' cyklotrás. Za pomoci TSK sa zrealizovalo dôkladné zmapovane existujúcich cyklotrás a taktiež sa navrhli potenciálne cyklotrasy $\mathrm{v}$ regióne, ktoré by bolo možné pri získaní financií zrealizovat'.

Po ukončený programového obdobia 2007-2013 sa zmobilizovali aktéri na území MAS. Tento proces vyvrcholil v roku 2015, od kedy sa stretával prípravný výbor, ktorého aktivity vyústili do návrhu úprav stanov MAS, úprav interných smerníc a ich zosúladenia s požiadavkami systému riadenia CLLD pre programové obdobie 2014-2020. Následne sa schválila Stratégia CLLD pre územie MAS pre programové obdobie 2014-2020 valným zhromaždením združenia. V súčasnosti sa MAS podarilo získat' financie na stratégiu a jej fungovanie. $Z$ čoho vyplýva väčšia aktivita MAS v území v rôznych oblastiach, čiže aj v oblasti cestovného ruchu. Návrhy ako by mohla MAS podporit' rozvoj cestovného ruchu uvádzame $\mathrm{v}$ nasledujúcej kapitole.

\section{Konkrétne návrhy aktivít MAS Magura-Strážov na podporu rozvoja cestovného ruchu}

Po dlhom a náročnom procese sa podarilo získat' MAS financie $\mathrm{z}$ európskych fondov na jej fungovanie ako aj na rozvoj územia. Na základe tohto úspechu MAS sme navrhli opatrenia na zviditel'nenie daného územie a taktiež sme sa zamerali aj na rozvoj cestovného ruchu. Na zviditel'nenie územia MAS by bolo potrebné vytvorit' informačnú tabul'u, nakol'ko v tomto území sa nenachádza ani jedna informačná tabul'a, ktorá by poskytovala aspoň všeobecné informácie o MAS pre návštevníkov, prípadne i pre miestnych obyvatel'ov. Bolo by vhodné, aby bol pri každej informačnej tabuli umiestnený propagačný materiál, ktorý by informoval návštevníkov o možnostiach v oblasti turizmu a ostatných možností MAS. Tejto problematike sa venovala aj rigorózna práca Geografické aspekty regionálneho rozvoja miestnej akčnej skupiny Magura-Strážov, kde bola navrhnutá takáto informačná tabul'a (Kováč, 2017). Prostredníctvom informačno- 
propagačného materiálu vidíme potenciál na zviditel'nenie územia MAS MaguraStrážov.

Na základe dotazníkového prieskumu, kde takmer polovica zúčastnených obyvatel'ov (42\%) hodnotí kultúrno-spoločenské podujatia vel'mi pozitívne najmä o oblasti Bojníc a Nitrianskeho Rudna je potrebné do týchto spoločenských podujatí zapojit' aj ostatné obce v MAS. Jednou z možností, ako by sa dalo zviditel'nit' územie MAS, vidíme v propagácií mesta Bojnice smerom $\mathrm{k}$ MAS a $\mathrm{k}$ jej jednotlivým obciam. Mesto Bojnice má nielen regionálny, ale aj národný význam, kvôli jeho kultúrnemu a historickému potenciálu ho navštevuje každý rok vel'mi vel’a návštevníkov. Preto navrhujeme, aby sa počas týchto významných kultúrnych podujatí $\mathrm{v}$ meste Bojnice zvýšila snaha MAS o propagáciu celého územia, a to hlavne v oblasti turizmu a prírodných zaujímavosti, ako aj lokálnych produktoch. A to spôsobom prenosného stánku, ktorý by sa nachádzal v blízkosti Bojnického zámku tak, aby bol dobre viditelný návštevníkom. Kde by boli umiestnené informačné letáky, ktoré si môže návštevník vziat' so sebou. V prípade záujmu o d’alšie informácie by poverená osoba odpovedala priamo na mieste.

Podporovat' lokálne produkty v území MAS je vel'mi dôležité, pretože takéto produkty sú významné a ich originalitou dotvárajú charakter územia a tým sa podiel'ajú na rozvoji daného územia ako aj cestovného ruchu. $\mathrm{Na}$ základe výskumov Sykala et al. (2015), ktorý bol zameraný na realizované projekty MAS zahŕnajúce lokálne produkty a ich pozitívnych vplyvov na rozvoj vidieka a atraktivitu regiónov, sme sa rozhodli medzi návrhy zahrnút' aj projekt vytvorenia lokálnej predajne, ktorý by poskytol priestor pre predaj lokálnych produktov (potravinárske aj rôzne výrobky) a ul'ahčil pestovatel'om a výrobcom propagáciu a predaj produktov. Podpora produkcie a predaja lokálnych produktov prináša do regiónu hned' viacero výhod. Nielenže sú regióny tak atraktívnejšie pre turistov (gastroturistika, podujatia spojené s lokálnymi produktami), ale poskytujú aj ekonomický profit vo forme pracovných príležitostí a vyšších miezd, pomáhajú chránit' kultúrne dedičstvo a lokálne pestovanie (v najlepšom prípade agroekologické alebo bio pestovanie) prispieva k ochrane krajiny a udržatel'nosti.

Napriek tomu, že na území MAS je dostatočné množstvo podujatí, absentuje spoločné podujatie, na ktorom by sa podiel'ali všetky obce v rámci MAS. $\mathrm{Z}$ tohto dôvodu navrhujeme, aby MAS vytvorila $\mathrm{v}$ rámci ich možnosti čo najviac takýchto podujatí. Za vhodné miesto uskutočnenia vidíme obec Nitrianske Rudno, konkrétne oblast' pri priehrade. Toto miesto je vel'mi vhodné na uskutočnenie daného podujatia, vzhl'adom $\mathrm{k}$ tomu, že je to kempingová oblast' s dostačujúcou kapacitou. Na území jednotlivých obcí MAS sa nachádza dostatočné množstvo folklórnych a tanečných súborov, resp. hudobných kapiel, ktoré môžu tvorit' kultúrny základ podujatia. Rovnako by sa mohli prezentovat' jednotlivé zvyky a tradície v MAS, ako príklad uvádzame ukážku výroby krištál'ového skla. Jeho výroba má vel'kú tradíciu v obci Valaská Belá. Táto výroba v súčasnosti upadá, preto považujeme za vel'mi dôležité zachovat' túto tradičnú výrobu, čo by malo za 
následok rozvoj nielen cestovného ruchu ale aj zamestnanosti v MAS, pričom tieto pozitíva potvrdzuje práca Havena et. al (2012) či Panyika et al. (2011), ktoré sa zaoberajú vplyvom kultúrnych podujatí na rozvoj cestovného ruchu.

\section{Záver}

MAS Magura-Strážov bola založená v roku 2007 a odvtedy združuje v oblasti členov verejného, súkromného a občianskeho sektora. Bola vytvorená na základe princípu LEADER a jej hlavnou úlohou je rozvoj vidieka v oblasti na okraji pohorí Strážovské vrchy a Malá Magura, ktorá patrí do Trenčianskeho samosprávneho kraja. V roku 2015 MAS Magura-Strážov vypracovala dotazník, ktorý bol vhodným podkladom nielen pre vytvorenie stratégie MAS MaguraStrážov, ale aj pre zhodnotenie spokojnosti obyvatel'ov, vytýčenie nedostatkov, ktoré pocit'ujú, ale aj čo považujú za silné stránky územia.

Po analýze literatúry sme zistili, že problematike miestnych akčných skupín sa venujú v odborných publikáciách najmä krajiny ako Pol'sko, Španielsko, Taliansko, Slovinsko a Dánsko. Hlavnou témou je fungovanie a problémy, ktoré ovplyvňujú aktivity a výsledky MAS. Napriek tomu, že cestovný ruch môže byt' pre rozvoj vidieka vel'mi prínosný, publikácie o vplyve MAS na cestovný ruch chýbajú. Tento článok túto medzeru aspoň čiastočne vypĺn̆a.

Súčast’ou práce je taktiež vypracovaná SWOT analýza aktivít MAS MaguraStrážov. Ukazuje mnoho silných stránok ako napríklad jednoduchšia komunikácia a zdiel'anie informácií medzi stakeholdermi v území, možnosti spolupráce s inými organizáciami, usporadúvanie podujatí a rozvoj regiónu ako celku, ale aj problémy s tým súvisiace, ako nezhody pri rozhodovaní a nerovnomerne rozvinuté územie. Zobrazené sú však aj možnosti pre rozvoj.

MAS Magura-Strážov počas svojho pôsobenia zrealizovala už niekol'ko aktivít, ktoré podporujú cestovný ruch. Organizovala viacero kultúrnospoločenských podujatí a ako úspešný projekt hodnotí mapovanie cyklotrás a turistických trás $\mathrm{v}$ spolupráci s Trenčianskym samosprávnym krajom. Nielenže sa zmapovali existujúce cyklotrasy ale boli navrhnuté aj tie potenciálne, ktoré by mohli byt' vytvorené v budúcnosti.

Územie sledovanej MAS má vel'mi dobré predpoklady pre rozvoj cestovného ruchu. Vyvierajú tu atraktívne geotermálne vody, ktoré sa využívajú na rekreačné účely. Oblast' je hornatá a nachádza sa tu niekol'ko chránených území, ktoré poskytujú možnosti na horskú turistiku v zaujímavom prostredí (vyskytuje sa tu napríklad známy črievičník papučkový, Strážovské vrchy sú územím európskeho významu, Temešská skala so strmou skalnou stenou je krajinnou dominantou). Vodné nádrže majú široké využitie vrátane športových aktivít a organizovaní kultúrno-spoločenských podujatí ako sú koncerty. Známou obcou sú Bojnice, kde sa nachádzajú kúpele ale aj zoologická záhrada a zámok s mnohými kultúrnymi podujatiami. 
Na základe analýzy publikácií o aktivitách, ktoré majú priaznivý vplyv na rozvoj cestovného ruchu a potenciálu územia pre cestovný ruch sme vypracovali návrhy na kroky, ktoré MAS Magura-Strážov môže uskutočnit' a ktoré by podporili rozvoj trvalo udržatel'ného cestovného ruchu, medzi ktoré patrí napríklad lepšia propagácia územia prostredníctvom internetových stránok a sociálnych sietí, organizácia podujatí, vytvorenie a inštalácia informačných tabúl' a videa, ale aj podpora výroby a predaja lokálnych produktov.

MAS Magura-Strážov má potenciál a možnosti pre aktivity, ktoré by podporili rozvoj cestovného ruchu, je však potrebné udržat' pozitívnu spoluprácu medzi členmi MAS, zohl'adnit' nevyužitý potenciál územia pre cestovný ruch, nadväzovat' kontakty $\mathrm{s}$ d'alšími organizáciami a vykonávat' aktivity, ktoré podporujú najmä trvalo udržatel'ný cestovný ruch.

\section{Pod'akovanie}

Príspevok vznikol v rámci riešenia projektu VEGA č. 2/0051/17 financovaného Vedeckou grantovou agentúrou MŠVVŠ SR a SAV Hodnotenie kultúrnych ekosystémových služieb krajiny na báze krajinnoekologických výskumov pre ekologické modely rozvoja cestovného ruchu.

\section{Literatúra}

BOLTIŽIAR, M. 2001. Evaluation of vulnerability of high-mountain landscape on example Velická valley in the High Tatras Mts. In Ekológia (Bratislava). ISSN 1335-342X, 2001, vol. 20, supplement 4, pp. 101-109.

EURÓPSKA KOMISIA. 2010. Európa 2020. Stratégia na zabezpečenie inteligentného, udržatel'ného a inkluzívneho rastu. [cit. 2018-09-10]. Dostupné na internete: http://ec.europa.eu/eu2020/pdf/1_SK_ACT_part1_v1.pdf

FURMANKIEWICZ, M. 2012. LEADER+ territorial governance in Poland: successes and failures as a rational choice effect. In Journal of Economic and Social Geography. vol. 103, no. 3, pp. 261-275.

FURMANKIEWICZ, M. 2013. Co-governance or hidden domination of the public sector? The concept of governance in the practice of 'LEADER' local action groups. In Studia Regionalne i Lokalne. ISSN 1509-4995, 2013, vol. 51, no. 1, pp. 71-89.

HAVEN - TANG, C. - JONES, E. 2012. Local leadership for rural tourism development: A case study of Adventa, Monmouthshire, UK. In Tourism Management Perspectives. ISSN 2211-9736, 2012, no.4, pp. 28-35.

HENSEL, K. - KRNO, I. 2002. Zoogeografické členenie. Limnický biocyklus. Mierka 1 : 2000 000. In Atlas krajiny SR. Hrnčiarová, T. (red.). Bratislava: MŽP SR, Slovenská agentúra životného prostredia, 2002. 118 s. ISBN 8088833-27-2. 
INTEGROVANÝ REGIONÁLNY OPERAČNÝ PROGRAM 2014-2020 (IROP, 2014). 2014. Programový dokument SR.

JAKUBCOVA, A. - GREŽO, H. - HREŠKOVÁ, A. - PETROVIČ, F. 2016. Impacts of Flooding on the Quality of Life in Rural Regions of Southern Slovakia. In Applied Research in Quality of Life. ISSN 1871-2584, 2016, vol. 11, no. 1, pp. 221-237.

KOLÉNY, M. - BARKA, I. 1984. Fytogeografické členenie Európy. Mierka 1 : 20000 000. In Atlas krajiny SR. Hrnčiarová, T. (red.). Bratislava: MŽP SR, Slovenská agentúra životného prostredia, 2002. 112 s. ISBN 80-88833-27-2.

KOVÁČ, T. 2017. Geografické aspekty regionálneho rozvoja miestnej akčnej skupiny Magura-Strážov. [rigorózna práca]. Nitra: Univerzita Konštantína Filozofa v Nitre.

KOVÁČ, T. - LACO, I. - TURANOVIČOVÁ, M. - BOLTIŽIAR, M. 2018. Hodnotenie prírodných predpokladov MAS Magura-Strážov pre regionálny rozvoj. In XXI. mezinárodní kolokvium o regionálních vědách: sborník príspěvki̊. Kurdějov 13.-15.6.2018. Brno: Masarykova univerzita, 2018. ISBN 978-80-210-8969-3, s. 633-640.

LAPIN, M. a kol. 2002. Klimatické oblasti. Mierka 1 : 1000 000. In Atlas krajiny $S R$. Hrnčiarová, T. (red.) Bratislava :Slovenská agentúra životného prostredia, 2002. 113 s. ISBN 80-88833-27-2.

LIU, Y. D. 2014. Cultural events and cultural turism development: Lessons from European Capitals of Culture. In European Planning Studies. ISSN 469-5944, 2014, vol. 22, no. 3, pp. 498-514.

LOPOLITO, A. - NARDONE, G. - SISTO, R. 2011. Towards a Comprehensive Evaluation of Local Action Groups in LEADER Programmes. In New Medit. ISSN 1594-5685, 2011, vol. 10, no. 1, pp. 43-49.

LUKNIŠ, M. a kol. 1972. Slovensko 2 príroda. 1 vyd. Bratislava: Obzor, 1972. $920 \mathrm{~s}$.

METODICKÁ PRÍRUČKA PRE MIESTNE AKČNÉ SKUPINY PRÍSTUP LEADER NR SAMOSPRÁVNY KRAJ (Leader SVK, 2010). 2010. [cit. 201809-09]. Dostupné na internete: https://www.leadernsk.sk/images/ prirucky/leader_SVK_konecna.pdf

MINISTERSTVO PÔDOHOSPODÁRSTVA A ROZVOJA VIDIEKA SR. (PRV SR 2014-2020). [cit. 2018-09-09.]. Dostupné na internete: http://www.mpsr.sk/index.php?navID=47\&sID=43\&navID2=935

NARIADENIE EURÓPSKEHO PARLAMENTU A RADY (EÚ) č. 1303/2013. [cit. 2018-09-09]. Dostupný na internete: https://eur-lex.europa. eu/legal-content/sk/TXT/?uri=celex\%3A32013R1303

NÁRODNÁ SIEŤ ROZVOJA VIDIEKA SR. (NSRV, 2015a). 2015. CLLD. [cit. 2018-09-09]. Dostupné na internete: http://www.nsrv.sk/?pl=70.

NÁRODNÁ SIEŤ ROZVOJA VIDIEKA SR. (NSRV, 2015b). 2015. Čo sú MAS. [cit. 2018-09-09]. Dostupné na internete: http://nsrv.sk/?pl=19 
NAVARRO, F. - CEJUDO, E. - MAROTO, J. 2016. Participation of disadvantaged groups and governance in the LEADER and PRODER programmes in Andalucía, Spain. In Studies in Agricultural Economics. ISSN 1418-2106, 2016, vol. 118, pp. 47-54.

NAVARRO, F. et al. 2018. Interpretations of innovation in rural development. The cases of LEADER projects in Lecce (Italy) and Granada (Spain) in 2007-2017 period. In European Countryside. ISSN 1803-8417, 2018, vol. 10, no. 1, pp. 107-126.

PANYIK, E. - COSTA, C. - RÁTZ, T. 2011. Implementing integrated rural tourism: An event-based approach. In Tourism Management. ISSN 0261-5177, 2011, vol. 32, pp. 1352-1363.

PAUL, A. 2015. A comparative analysis of the LAG Tara Oasuli and Tara Oltuluias romanian management strategies. In Agricultural Management Strategies in a Changing Economy. Hershey: Business Science Reference, 2015. ISBN 1466675217, pp. 379-400.

PETROVIČ, F. - MUCHOVÁ, Z. 2013. The potential of the landscape with dispersed settlement (case study Cadca town). In Public recreation and landscape protection - with man hand in hand: Conference proceedings. Brno 1.-3.5.2013. Brno: Mendlova univerzita, 2013. ISBN 978-80-7375-746-5, s. 199-204.

PISANI, E. et al. (eds.) 2015. Social capital and local development. Cham: Springer International Publishing AG, 2015. 516 p. ISBN 978-3-319-54276-8.

PROGRAM ROZVOJA VIDIEKA 2014-2020 (PRV). [cit. 2018-09-10]. Dostupné na internete: http://www.apa.sk/index.php?start\&navID=496

STRATÉGIA MIESTNEHO ROZVOJA VEDENÉHO KOMUNITOU (STRATÉGIA CLLD) MIESTNEJ AKČNEJ SKUPINY MAGURASTRÁŽOV 2014-2020. 2015. 217 s.

SYKALA, L. - DEJ, M. - JARCZEWSKI, W. 2015. Distribution of LEADER support designed to local agricultural products in Poland. In Agricultural Resources, Governance and Ecology. ISSN 1462-4605, 2015, vol. 11, no. 2, pp. 123-142.

THUESEN, A. A. 2010. Is LEADER Elitist or Inclusive? Composition of Danish LAG Boards in the 2007-2013 Rural Development and Fisheries Programmes. In Sociologia Ruralis. ISSN 1467-9523, 2010, vol. 50, no. 1, pp. 31-45.

VOLK, A. - BOJNEC, Š. 2014. Local action groups and the LEADER cofinancing of rural development projects in Slovenia. In Agricultural Economics - Czech. ISSN 0139-570X, 2014, vol. 60, no. 8., pp. 364-375.

WISTEROVÁ, A. 2016. Verejno-súkromné partnerstvá: Miestne akčné skupiny (MAS) [cit. 2018-09-09]. Dostupné na internete: http://casopisgrant.sk/ verejnosukromne-partnerstva-miestne-akcne-skupiny-mas/

ZÁKON č. 83/1990 Zb. o združovaní občanov. 


\section{IMPACT OF LOCAL ACTION GROUPS TO SUPPORT OF TOURISM DEVELOPMENT - CASE STUDY LOCAL ACTION GROUP(LAG) MAGURA-STRÁŽOV}

\section{Summary}

Since LAG Magura-Strážov was founded in 2007, it has been merging members of public, privat and civil sectors in the area. The LAG is based on LEADER principle and its main focus is developlment of countryside in the territory that is part of Trenčiansky autonomous region, on the edge of the mountines Strážovské vrchy and Malá Magura. In 2015 LAG Magira-Strážov elaborated a questionair that is a suitable base not only for creation of LAG strategy, but also for evaluation of local population satisfaction, setting out of shortcomings they had been experiencing and what they consider as advantages of the area

According to analysis of literature we had made we came to a conclusion that the scientific publications that are focused on LAGs comes mainly from Poland, Spain, Italy, Slovenia and . The main topics are LAGs functioning and problems that are impacting their activities and outcomes. Even though tourism could be really beneficial for rural development, research papers discussing this topic are missing. This article partly fills the gap in research.

SWOT analysis of LAG Magura-Strážov activities is part of our work too. It is showing many strenghts, for exmaple easier comunication and sharing of information between stakeholders in the area, opportunities for cooperation with different organizations, organization of events and development of region as a entirety, but also relaated problems as disagreaments in decision-making and unevenly developed districts. It is displaying also opportunities for development

LAG Magura-Strážov has already implemented some activities that support tourism. Several socio-cultural events were organized. The project of mapping of bike and hiking trails in cooperation with Trenčiansky autonomous region is considered as really succesful. Not only existing trails were mapped but also some potential ones have been proposed and with enough funds could be established in the future.

The area of the studied LAG has good assumptions for development of tourism. Atractive geotermal waters rise here and are used for recreational purposes. The reagion is mountainous and many protected areas are located here that provide many opportunities for hiking in an interesting environment (Lady's Slipper Orchid-Cypripedium calceolus occurs here, Strážovské vrchy is an area of european significance, Temešská skala with its steep rock wall is a landscape dominat). Water tanks have a wide use including sport activities, and providing suitable space for events as for example concerts. Really popular is the commune Bojnice where spa health resorts are located and the oldest zoo in Slovakia with castle (a place for many cultural events) are nearby. 
Based on analysis of publications focused on activities supporting development of tourism and potential of the area for tourism, suggestions of activities that the LAG could realize for better support of sustainable tourism development were proposed. For example better propagation of the region via websites and social networks, even organization, creating and installation of information boards and videos as well as support of production and sale of local products.

LAG Magura-Strážov has potential and possibilities for activities that can support development of sustainable tourism. However, it is needed to maintain positive cooperation of the LAG members, take into account unused potential of the region for tourism, establish contacts with more organizations and highly prefer activities that support mainly sustainable tourism.

\section{RNDr. Tomáš Kováč}

Katedra ekológie a environmentalistiky FPV UKF v Nitre

Trieda A. Hlinku 1, 94974 Nitra

E-mail: tomas.kovac@ukf.sk

\section{Mgr. Ivan Laco}

Katedra ekológie a environmentalistiky FPV UKF v Nitre

Trieda A. Hlinku 1, 94974 Nitra

E-mail: ivan.laco@ukf.sk

\section{Mgr. Michaela Kalivodová}

Katedra ekológie a environmentalistiky FPV UKF v Nitre

Trieda A. Hlinku 1, 94974 Nitra

E-mail: michaela.kalivoodva@ukf.sk

Prof. PhDr. RNDr. Martin Boltižiar, PhD.

Ústav krajinnej ekológie SAV Bratislava - pobočka Nitra Akademická 2, 94901 Nitra

E-mail: martin.boltiziar@savba.sk 